\title{
Karakteristik Ekstrak Pewarna Alami Bunga Kenop (Gomphrena globosa L.) pada Perlakuan Jenis Pelarut dan Suhu Ekstraksi serta Korelasi antar Variabel The Characteristics of Natural Dye Extract of Globe Amaranth (Gomphrena globosa L.) on The Treatment of Solvent Types and Extraction Temperature and Correlation Between Variables
}

\author{
Zainul Fikri, Ni Made Wartini*, Luh Putu Wrasiati \\ PS Teknologi Industri Pertanian, Fakultas Teknologi Pertanian, Universitas Udayana, Kampus Bukit \\ Jimbaran, Badung, Kode pos : 80361; Telp/Fax : (0361) 701801
}

Diterima 19Agustus 2020 / Disetujui 27 Agustus 2020

\begin{abstract}
Globe amaranth is one of the flowers contain betacyanin that potentially used as natural dye by extracting. This research aimed to find out the characteristics of natural dye extract of globe amaranth on the treatment of solvent types and extraction temperature as well as to determine the correlation between a total of betacyanin with the yield and color intensity of the natural dye extract of globe amaranth. This experiment was designed using two factors. The first factor was solvent types consisting of aquades, ethanol 48 percent, and ethanol 96 percent. The second factor was the extraction temperature consisting of 25,35 , and $45^{\circ} \mathrm{C}$. The data analysis used a bivariate correlation test. The results showed the characteristics of the natural dye extract of globe amaranth on the treatment of the type of solvent and extraction temperature were as follows: yield of $8.65-16.13$ percent, betacyanin total $30.01-185.51 \mathrm{mg} / 100 \mathrm{~g}$, brightness level $\left(L^{*}\right) 12.08-17.09$, redness level $(a *) 8.19-10.93$, and yellowish level $\left(b^{*}\right) 4.77-7.87$. A total of betacyanin was positively correlated with yield and the redness level $\left(a^{*}\right)$ with correlation coefficient value ( $\left.r\right) 0.504$ (strong) and 0.986 (very strong) and determination coefficient value (R2) 0.2541 and 0.9719, while a total of betacyanin was negatively correlated with the brightness level $\left(L^{*}\right)$ and the yellowish level $\left(b^{*}\right)$ with the correlation coefficient value ( $r$ ) -0.932 (very strong) and -0.907 (very strong) and determination coefficient value (R2) 0.8679 and 0.8226 .
\end{abstract}

Keywords: Gomphrena globosa L., betacyanin, extraction, correlation.

\section{ABSTRAK}

Bunga kenop merupakan salah satu bunga yang mempunyai kandungan betasianin yang berpotensi digunakan sebagai pewarna alami dengan cara diekstraksi. Penelitian ini bertujuan untuk mengetahui karakteristik ekstrak pewarna alami bunga kenop pada perlakuan jenis pelarut dan suhu ekstraksi serta menentukan korelasi antara total betasianin dengan rendemen dan intensitas warna ekstrak pewarna alami bunga kenop. Percobaan ini dirancamg menggunakan dua faktor. Faktor pertama yaitu jenis pelarut yang terdiri atas akuades, etanol 48 persen, dan etanol 96 persen. Faktor kedua yaitu suhu ekstraksi yang terdiri atas 25,35 , dan $45^{\circ} \mathrm{C}$. Analisis data menggunakan uji korelasi bivariat. Hasil penelitian menunjukkan karakteristik ekstrak pewarna alami bunga kenop pada perlakuan jenis pelarut dan suhu ekstraksi adalah sebagai berikut : rendemen 8,65 - 16,13 persen, total betasinain 30,01 -

*Korespondensi Penulis:

Email: md_wartini@unud.ac.id 
185,51 mg/100g, tingkat kecerahan ( $\left.\mathrm{L}^{*}\right)$ 12,08 - 17,09, tingkat kemerahan (a*) 8,19-10,93, dan tingkat kekuningan $\left(b^{*}\right) 4,77-7,87$. Total betasianin berkorelasi positif dengan rendemen dan tingkat kemerahan $\left(\mathrm{a}^{*}\right.$ ) dengan nilai koefisien korelasi (r) sebesar 0,504 (kuat) dan 0,986 (sangat kuat) sertanilai koefisien determinasi (R2) sebesar 0,2541 dan 0,9719, sedangkan total betasianin berkorelasi negatif dengan tingkat kecerahan $\left(\mathrm{L}^{*}\right)$ dan tingkat kekuningan $\left(\mathrm{b}^{*}\right)$ dengan nilai koefisien korelasi (r) sebesar 0,932 (sangat kuat) dan -0,907 (sangat kuat) serta nilai koefisien determinasi (R2) sebesar 0,8679 dan 0,8226 .

Kata kunci: Gomphrena globosa L., betasianin, ekstraksi, korelasi.

\section{PENDAHULUAN}

Zat pewarna merupakan salah satu komponen penting baik bagi industri pangan maupun non pangan untuk menghasilkan produk yang lebih menarik. Pada industri pangan zat pewarna dapat digunakan sebagai bahan tambahan makanan yang dapat memperbaiki atau memberi warna pada makanan (Permenkes RI, 1988). Berdasarkan sumbernya pewarna makanan diklasifikasikan menjadi dua macam yaitu pewarna alami dan pewarna sintetik. Penggunaan zat pewarna alami lebih aman dikonsumsi dikarenakan berasal dari bahan alami. Pada dasarnya mengkonsumsi pewarna makanan sintetik dalam jangka waktu yang lama akan berdampak negatif bagi kesehatan seperti timbulnya penyakit kanker mulut, kanker kulit, dan kerusakan otak (Winarno dan Sulistyowati, 1994).

Bunga kenop merupakan bunga yang berasal dari Amerika tropis yang kini sudah banyak dibudidayakan di Indonesia. Bunga dengan nama latin Gomphrena globosa L. ini merupakan jenis tanaman dari keluarga Amaranthaceae yang dapat ditemukan sepanjang tahun. Pada umumnya bunga kenop berwarna merah tua keunguan, merah muda, atau putih (Dalimartha, 2000). Bunga ini sangat berpotensi dimanfaatkan sebagai pewarna alami, hal ini dikarenakan kandungan alami pigmen betasianin yang terkandung di dalamnya. Betasianin merupakan pigmen dengan warna merah keunguan dengan nilai serapan maksimum pada panjang gelombang 534 - $555 \mathrm{~nm}$ (Coultate, 1996). Cai et al. (2001) melaporkan bunga yang berasal dari keluarga Amaranthaceae banyak mengandung pigmen alami betasianin, dimana pada bunga kenop dalam keadaan segar mengandung 130 $\mathrm{mg} / 100 \mathrm{~g}$ betasianin.

Zat pewarna dari bunga kenop dapat diperoleh dengan menggunakan metode ekstraksi. Ekstraksi merupakan proses penarikan kandungan kimia yang dapat larut dari suatu serbuk simplisia, sehingga terpisah dari bahan yang tidak dapat larut (Depkes RI, 2006). Beberapa faktor yang mempengaruhi proses ekstraksi diantaranya yaitu jenis pelarut, suhu, konsentrasi pelarut, ukuran partikel, pH, dan lama ekstraksi (Chew et al., 2011). Faktor jenis pelarut dan suhu ekstraksi dapat mempengaruhi karakteristik ekstrak pewarna alami yang dihasilkan. Pemilihan jenis pelarut didasarkan pada nilai konstanta dielektrum pelarut harus proporsional dengan polaritas senyawa yang akan diekstrak, sedangkan pemilihan suhu ekstraksi didasarkan pada suhu maksimum kestabilan senyawa yaitu kelarutan bahan dan difusifitas akan meningkat seiring kenaikan suhu.

Berdasarkan penelitian yang dilakukan oleh Rengku et al. (2017) penggunaan pelarut akuades pada ekstraksi betasianin buah kaktus merupakan perlakuan terbaik dengan kadungan total betasianin sebesar 15,42 mg/100 g. Khuluq et al. (2007) melaporkan pada ekstraksi betasianin daun darah, penggunaan jenis pelarut akuades dan etanol dengan rasio 5:5 (v/v) merupakan perlakuan terbaik, hasil yang didapatkan yaitu rendemen $81,05 \%$ dan total betasianin sebesar 45,81 mg/100 g. Hasil ini sesuai 
dengan pernyataan Naderi et al. (2012) bahwa penggunaan campuran pelarut akuades-etanol (50:50) dapat secara selektif mengekstraksi pigmen betasianin sekaligus mengendapkan pektin.

Selain itu perlakuan suhu ekstraksi juga terbukti berpengaruh terhadap karakteristik ekstrak pewarna yang dihasilkan. Berdasarkan

penelitian yang dilakukan oleh Roriz et al. (2017), pada ekstraksi betasianin bunga kenop penggunaan suhu $25^{\circ} \mathrm{C}$ merupakan perlakuan terbaik dengan proses ekstraksi selama 165 menit, jenis pelarut akuades, dan rasio bahan dengan pelarut $5 \mathrm{~g} / \mathrm{L}$. Hasil yang didapatkan yaitu rendemen sebesar 51,9 $\pm 1,4$ $\%$ dan total betasianin $45,1 \pm 1,3 \mathrm{mg} / \mathrm{g}$. Pengaruh suhu ini sejalan dengan pernyataan Yulianti et al. (2008), bahwa betasianin mudah terdegradasi pada suhu di atas $40^{\circ} \mathrm{C}$. Sehingga pada proses ekstraksi betasianin lebih baik dilakukan pada suhu dibawah atau pada suhu $40^{\circ} \mathrm{C}$.

Disamping itu analisis korelasi perlu dilakukan untuk mengetahui keeratan serta pola hubungan antar variabel. Kristamtini et al. (2017) melaporkan bahwa antosianin total berkorelasi negatif dengan kecerahan $\left(\mathrm{L}^{*}\right)$ dan kemerahan $\left(a^{*}\right)$ dengan nilai koefisien korelasi (r) yaitu sebesar -0,568 dan -0,561, sedangkan antosianin total berkorelasi positif dengan kekuningan $\left(b^{*}\right)$ dengan nilai koefisien korelasi (r) sebesar 0,844.

Ekstraksi betasianin dari bunga kenop belum banyak dilakukan, oleh karena itu perlu dilakukan penelitian mengenai karakteristik ekstrak pewarna alami bunga kenop (Gomphrena globosa L.) pada perlakuan jenis pelarut dan suhu ekstraksi serta korelasi antar variabel. Tujuan penelitian ini yaitu untuk mengetahui karakteristik ekstrak pewarna alami bunga kenop pada perlakuan jenis pelarut dan suhu ekstraksi serta menentukan korelasi antara total betasianin dengan rendemen dan intensitas warna ekstrak pewarna alami bunga kenop.

\section{METODE PENELITIAN}

\section{Tempat dan Waktu}

Penelitian ini dilakukan di

Laboratorium Rekayasa Proses dan Pengendalian Mutu, Laboratorium Analisis Pangan, Laboratorium Teknik Pasca Panen, Fakultas Teknologi Pertanian, Universitas Udayana. Waktu pelaksanaan penelitian pada Januari hingga Maret 2020.

\section{Bahan dan Alat}

Bahan yang digunakan dalam penelitian ini yaitu bunga kenop yang diperoleh dari Jalan Sedap Malam, Desa Kesiman, Kecamatan Denpasar Timur, Kota Denpasar, Provinsi Bali. Kriteria bunga kenop yaitu berwarna ungu terang seragam, berbentuk bulat, dan tinggi bagian bunga 20$25 \mathrm{~mm}$. Bahan kimia yang digunakan yaitu akuades (Bratachem), etanol teknis 96\% (Bratachem), dan buffer sitrat-pospat $\mathrm{pH} 5$ (pa) (E. Merck). Peralatan yang digunakan dalam penelitian ini antara lain oven (Blue $\mathrm{M}$ ), rotatory evaporator (Buchi R-300 tipe V), spektofotometer (Biochrome SN 133467), timbangan analitik (Shimadzu), vortex (Barnstead Thermolyne Maxi Mix II), blender (Philips), timbangan analitik (Shimadzu), ayakan 80 mesh (Retsch), color reader (Accuprobe HH-06), kompor (Rinnai), termometer, dan alat-alat gelas.

\section{Rancangan Percobaan}

Percobaan ini dirancang menggunakan dua faktor. Faktor pertama adalah jenis pelarut $(\mathrm{P})$ yang terdiri atas tiga taraf, yaitu P1 (Akuades), P2 (Etanol 48 persen), dan P3 (Etanol 96 persen). Faktor kedua yaitu suhu ekstraksi (S) yang terdiri atas tiga taraf, yaitu $\mathrm{S} 1\left(25 \pm 2^{\circ} \mathrm{C}\right), \mathrm{S} 2\left(35 \pm 2^{\circ} \mathrm{C}\right)$, dan S3 $\left(45 \pm 2^{\circ} \mathrm{C}\right)$. Dari 2 faktor diperoleh 9 kombinasi perlakuan dan dianalisis sebanyak dua kali (duplo). Data obyektif yang diperoleh 
dianalisis menggunakan program Microsoft Excel 2010 dan uji korelasi bivariat menggunakan program SPSS 25. Data disajikan dalam bentuk grafik.

\section{Pelaksanaa Penelitian Preparasi Sampel}

Bunga kenop dihilangkan kelopaknya dan dicuci menggunakan air hingga bersih. Selanjutnya dilakukan blansir pada suhu $95 \pm 2^{\circ} \mathrm{C}$ selama 1 menit dan didinginkan dengan air mengalir (Pangesti, 2018). Bunga kenop kemudian dikeringkan menggunakan suhu $40 \pm 5^{\circ} \mathrm{C}$ hingga mudah dihancurkan (kadar air 8,44\%). Selanjutnya dihaluskan menggunakan blender dan diayak menggunakan ayakan ukuran 80 mesh.

\section{Ekstraksi Bunga Kenop}

Proses ekstraksi bunga kenop dilakukan dengan metode maserasi. Sebanyak 20 gram bubuk bunga kenop ditimbang dan ditambah pelarut sesuai perlakuan yaitu akuades, etanol 48 persen, dan etanol 96 persen sebanyak $220 \mathrm{ml}$ (1:11) (b/v) (Yudharini et al., 2016). Selanjutnya dilakukan proses maserasi pada suhu sesuai perlakuan yaitu $25^{\circ} \mathrm{C}, 35^{\circ} \mathrm{C}$, dan $45^{\circ} \mathrm{C}$ selama 24 jam. Selama maserasi, dilakukan pengadukan secara manual selama 5 menit setiap 6 jam. Larutan kemudian disaring menggunakan kertas saring kasar dan menghasilkan filtrat I dan residu yang berupa ampas. Residu dibilas dengan pelarut sesuai perlakuan sebanyak $20 \mathrm{ml}$ dan kemudian disaring dengan kertas saring kasar dan menghasilkan filtrat II. Filtrat I dan II yang diperoleh digabung, kemudian disaring dengan kertas saring Whatman No.1. Filtrat yang diperoleh kemudian dievaporasi menggunakan rotary evaporator vacum pada suhu $50^{\circ} \mathrm{C}$ dengan tekanan 100 mbar. Evaporasi dihentikan pada saat semua pelarut sudah menguap yang ditandai dengan tidak adanya tetesan pelarut. Ekstrak kental tersebut dimasukkan ke dalam botol sampel dan kemudian dianalisis

\section{Variabel yang Diamati}

Variabel yang diamati dalam penelitian ini yaitu rendemen (AOAC, 1999), kadar total betasianin (Eder, 1996), dan intensitas warna yaitu kecerahan, kemerahan, dan kekuningan. ( $\mathrm{L}^{*}, \mathrm{a}^{*}$, dan $\mathrm{b}^{*}$ dalam Weaver, 1996).

\section{Rendemen Ekstrak (AOAC, 1999)}

Rendemen dihitung menurut AOAC (1999). Rendemen merupakan hasil bagi dari berat ekstrak yang dihasilkan dibagi dengan berat bahan baku dikali 100\%. Dirumuskan sebagai berikut :

Rendemen $(\%)=\frac{\text { Berat ekstrak kental }(\mathrm{g})}{\text { Berat bubuk }(\mathrm{g})} \times 100 \%$

\section{Kadar Total Betasianin (Eder, 1996)}

Penentuan kadar total betasianin dengan metode Eder (1996). Sebanyak 0,01 gram ekstrak kental dilarutkan dalam pelarut buffer sitrat-fosfat $\mathrm{pH} 5$ sebanyak $5 \mathrm{ml}$. Selanjutnya dihomogenkan menggunakan vortex (Barnstead Thermolyne Maxi Mix II) dan diukur nilai absorbansinya menggunakan spektofotometer (Biochrome SN 133467) dengan panjang gelombang $537 \mathrm{~nm}$ dan 600 $\mathrm{nm}$. Nilai absorbansi dihitung dengan $\mathrm{A}=$ $1,095(\lambda 537-\lambda 600)$. Selanjutnya dilakukan penentuan kadar total betasianin menggunakan persamaan sebagai berikut :

Total Betasianin $\left(\frac{m g}{L}\right)=\frac{\mathrm{A} \times \mathrm{MW} \times \mathrm{FP} \times 1000}{\varepsilon \times \mathrm{L}}$

Keterangan :

$\mathrm{A}=$ Absorbansi

MW = Berat molekul betanin $550 \mathrm{~g} / \mathrm{mol}$

$\mathrm{FP} \quad=$ Faktor pengenceran

$\varepsilon=$ Koefisien ekstensi molar 60.000 $\mathrm{L} / \mathrm{mol} \mathrm{cm}$

$\mathrm{L} \quad=$ Tebal kuvet $(1 \mathrm{~cm})$

Total Betasianin $\left(\frac{m g}{100 g}\right)=\frac{\mathrm{X} \times \mathrm{V} \times 1000 \times 100}{\mathrm{~W}}$ 
Keterangan :

$\begin{array}{ll}\mathrm{X} & =\text { Konsentrasi persamaan awal } \\ & (\mathrm{mg} / \mathrm{L}) \\ \mathrm{V} & =\text { Volume }(\mathrm{L}) \\ \mathrm{W} & =\text { Berat sampel }(\mathrm{mg})\end{array}$

\section{Intensitas Warna (Sistem L,a,b dalam Weaver, 1996)}

Pengukuran intensitas warna dari ekstrak bunga kenop dilakukan dengan menggunakan color reader, sampel ekstrak bunga kenop ditempatkan pada cawan petri kemudian color reader dihidupkan dan pada tombol pembacaan diatur pada $L^{*}, a^{*}, b^{*}$. Tombol L untuk kecerahan (lightness), a untuk kemerahan dan b untuk kekuningan. Intensitas warna diukur dengan menekan tombol target.

\section{HASIL DAN PEMBAHASAN}

\section{Rendemen}

Hasil analisis menunjukkan perlakuan jenis pelarut dan suhu ekstraksi menghasilkan rendemen ekstrak pewarna alami bunga kenop berkisar antara 8,59 - 16,13 persen. Rendemen ekstrak pewarna alami bunga kenop dapat dilihat pada Gambar 1.

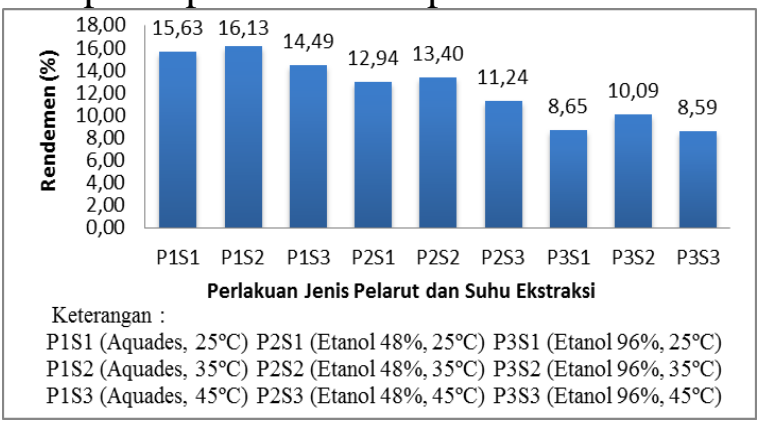

Gambar 1. Rendemen ekstrak pewarna alami bunga kenop pada perlakuan jenis pelarut dan suhu ekstraksi.

Gambar 1 menunjukkan bahwa rendemen ekstrak bunga kenop tertinggi dihasilkan pada perlakuan jenis pelarut akuades dan suhu ekstraksi $35^{\circ} \mathrm{C}$ yaitu sebesar 16,13 persen, sedangkan rendemen ekstrak bunga kenop terendah dihasilkan pada perlakuan jenis pelarut etanol 96 persen dan suhu $45^{\circ} \mathrm{C}$ yaitu sebesar 8,59 persen. Hasil ini menunjukkan bahwa peningkatan rendemen ekstrak yang dihasilkan seiring dengan peningkatan polaritas pelarut yang digunakan. Nilai polaritas pelarut berbading lurus dengan nilai konstanta dielektrik pelarut, yaitu akuades merupakan pelarut dengan polaritas terbesar dengan nilai konstanta dielektrik sebesar 80,37, kemudian etanol 48 persen sebesar 52,34, dan etanol 96 persen sebesar 24,30. Semakin tinggi polaritas pelarut maka rendemen yang dihasilkan semakin tinggi. Hal ini disebabkan ikut terekstraknya senyawa polar lain selain betasianin seperti gula selama proses ekstraksi. Hasil ini didukung oleh penelitian yang dilakukan oleh Lestari et al. (2017) tentang ekstraksi senyawa rasa awal pada daun sindu yang menghasilkan rendemen optimum berturut-turut pada pelarut akuades, etanol 48 persen, dan etanol 96 persen.

Perlakuan suhu ekstraksi pada semua jenis pelarut menunjukkan adanya peningkatan persentase rendemen ekstrak dari suhu $25^{\circ} \mathrm{C}$ ke $35^{\circ} \mathrm{C}$, namun mengalami penurunan pada suhu $45^{\circ} \mathrm{C}$. Damanik et al. (2014) menyatakan bahwa peningkatan suhu pada proses maserasi akan mempercepat perpindahan masa dari solut ke solven, sehingga nilai koefisien transfer masa dari suatu komponen akan semakin meningkat. Pada suhu $35{ }^{\circ} \mathrm{C}$ diperkirakan proses ekstraksi telah mencapai suhu optimum, sehingga pada perlakuan suhu $45^{\circ} \mathrm{C}$ menyebabkan penurunan persentase rendemen ekstrak, hal ini diduga pada suhu tersebut senyawa aktif pada bahan telah mengalami kerusakan sehingga proses ekstraksi tidak optimal. Penggunaan suhu yang terlalu tinggi pada proses ekstraksi dapat mengakibatkan rendahnya rendemen yang dihasilkan (Margaretta et al., 2011). 


\section{Total Betasianin}

Hasil analisis menunjukkan perlakuan jenis pelarut dan suhu ekstraksi menghasilkan total betasianin ekstrak pewarna alami bunga kenop berkisar antara 30,01 - 185,51 $\mathrm{mg} / 100 \mathrm{~g}$. Total betasianin ekstrak pewarna alami bunga kenop dapat dilihat pada Gambar 2.

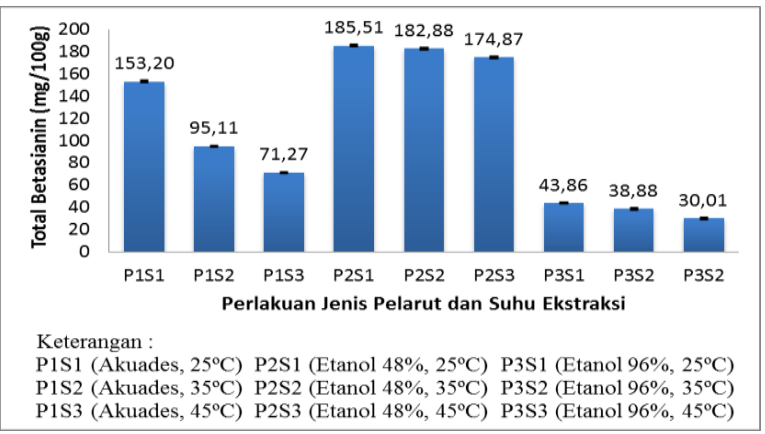

Gambar 2. Total betasianin ekstrak pewarna alami bunga kenop pada perlakuan jenis pelarut dan suhu ekstraksi.

Gambar 2 menunjukkan total betasianin ekstrak bunga kenop tertinggi dihasilkan pada perlakuan jenis pelarut etanol 48 persen dan suhu $25^{\circ} \mathrm{C}$ yaitu sebesar $185,51 \pm 0,67 \mathrm{mg} / 100 \mathrm{~g}$ sedangkan total betasianin terendah dihasilkan pada perlakuan jenis pelarut etanol 96 persen dan

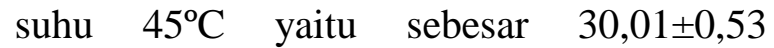
$\mathrm{mg} / 100 \mathrm{~g}$. Penggunaan jenis pelarut etanol 48 persen menghasilkan total betasianin tertinggi, sedangkan jenis pelarut etanol 96 persen menghasilkan total betasianin terendah. Hasil ini menunjukkan bahwa penggunaan jenis pelarut dengan polaritas yang mendekati tingkat polaritas betasianin akan mengoptimalkan proses ekstraksi dan memperbesar konsentrasi total betasianin yang dihasilkan. Proses penarikan bahan terjadi karena mengalirnya pelarut ke dalam sel sehingga terjadi pembengkakan protoplasma, dan bahan yang terkandung dalam sel akan terlarut sesuai dengan tingkat kelarutanya (Voight, 1994). Hasil penelitian ini juga didukung oleh pernyataan Naderi et al. (2012) bahwa penggunaan kombinasi pelarut akuades-etanol (50:50) dapat secara selektif mengekstrak pigmen betasianin lebih tinggi dibandingkan penggunaan etanol.

Perlakuan suhu ekstraksi menunjukkan menunjukkan bahwa total betasianin mengalami penurunan seiring peningkatan suhu ekstraksi yang digunakan pada semua jenis pelarut. Hal ini dikarenakan penggunaan suhu ekstraksi yang tinggi menyebabkan kerusakan pada komponen betasianin pada proses ekstraksi sehingga mengalami penurunan secara bertahap. Peningkatan suhu yang digunakan dapat menyebabkan terdegradasinya betasianin menjadi dekarboksilat betanin yang menyebabkan turunya konsentrasi betasianin (Stinzing et al., 2004). Suhu ekstraksi $45^{\circ} \mathrm{C}$ menghasilkan konsentrasi total betasianin terendah, hal ini diduga terjadi karena senyawa betasianin telah mengalami kerusakan sehingga betasianin yang terekstrak mengalami penurunan. Yulianti et al. (2008) menyatakan bahwa pigmen betasianin stabil pada suhu di bawah $40^{\circ} \mathrm{C}$, penggunaan suhu diatas $40^{\circ} \mathrm{C}$ mengakibatkan terjadinya perubahan warna secara cepat dari merah menjadi oranye kemudian kuning. Hal ini terjadi karena terjadinya dekomposisi betasianin akibat reaksi hidrolisis. Reaksi hidrolisis menyebabkan terjadinya dekomposisi betasianin menjadi asam betalamat dan sikloDOPA 5-O-glikosida (Herbach et al., 2006).

\section{Tingkat Kecerahan $\left(\mathbf{L}^{*}\right)$}

Hasil analisis menunjukkan perlakuan jenis pelarut dan suhu ekstraksi menghasilkan tingkat kecerahan $\left(\mathrm{L}^{*}\right)$ ekstrak pewarna alami bunga kenop berkisar antara 12,08 - 17,09. Nilai kecerahan $\left(\mathrm{L}^{*}\right)$ menyatakan tingkat gelap sampai terang dengan kisaran $0-100$. Tingkat kecerahan $\left(\mathrm{L}^{*}\right)$ ekstrak pewarna alami bunga kenop dapat dilihat pada Gambar 3. 


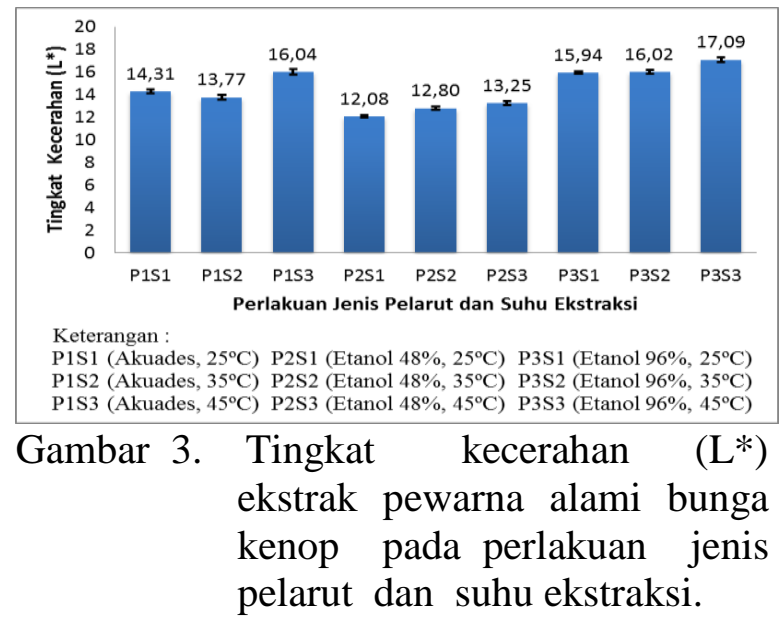

Gambar 3 menunjukkan tingkat kecerahan $\left(\mathrm{L}^{*}\right)$ ekstrak bunga kenop terendah pada perlakuan jenis pelarut etanol 48 persen dan suhu $25^{\circ} \mathrm{C}$ yaitu sebesar $12,08 \pm 0,10$ sedangkan tingkat kecerahan $\left(\mathrm{L}^{*}\right)$ tertinggi pada perlakuan jenis pelarut etanol 96 persen dan suhu $45^{\circ} \mathrm{C}$ yaitu sebesar 17,09 $\pm 0,21$. Tingkat kecerahan $\left(\mathrm{L}^{*}\right)$ ekstrak bunga kenop mengalami penurunan berturut-turut pada perlakuan jenis pelarut etanol 96 persen, akuades, dan etanol 48 persen. Hasil inimenunjukkan bahwa konsentrasi betasianin yang tinggi dalam ekstrak akan menyebabkan ekstrak berwarna semakin gelap dan nilai $\mathrm{L}^{*}$ berkurang. Khuluq et al. (2007) menyatakan bahwa konsentrasi betasianin yang rendah menyebabkan intensitas warna merah rendah sehingga warna ekstrak tidak terlalu gelap.

Perlakuan suhu ekstraksi menunjukkan menunjukkan bahwa nilai $\mathrm{L}^{*}$ mengalami kenaikan seiring peningkatan suhu ekstraksi yang digunakan pada semua jenis pelarut. Hal ini dikarenakan kandungan total betasianin pada ekstrak mengalami penurunan seiring kenaikan suhu ekstraksi, sehingga warna ekstrak akan semakin terang. Khuluq et al. (2007) menyatakan bahwa proses pemanasan akan mengakibatkan terjadinya kerusakan pigmen betasianin akibat dekomposisi struktur pigmen betasianin sehingga terjadi pemucatan dan warna semakin terang. Peningkatan nilai kecerahan juga menunjukkan terjadinya kerusakan pada betasianin (Herbach et al., 2006).

\section{Tingkat Kemerahan (a*)}

Hasil analisis menunjukkan perlakuan jenis pelarut dan suhu ekstraksi menghasilkan tingkat kemerahan (a*) ekstrak pewarna alami bunga kenop berkisar antara 8,19 10,93. Nilai kemerahan $\left(a^{*}\right)$ menyatakan tingkat warna hijau sampai merah dengan kisaran -100 sampai +100 . Tingkat kemerahan $\left(\mathrm{a}^{*}\right)$ ekstrak pewarna alami bunga kenop dapat dilihat pada Gambar 4.

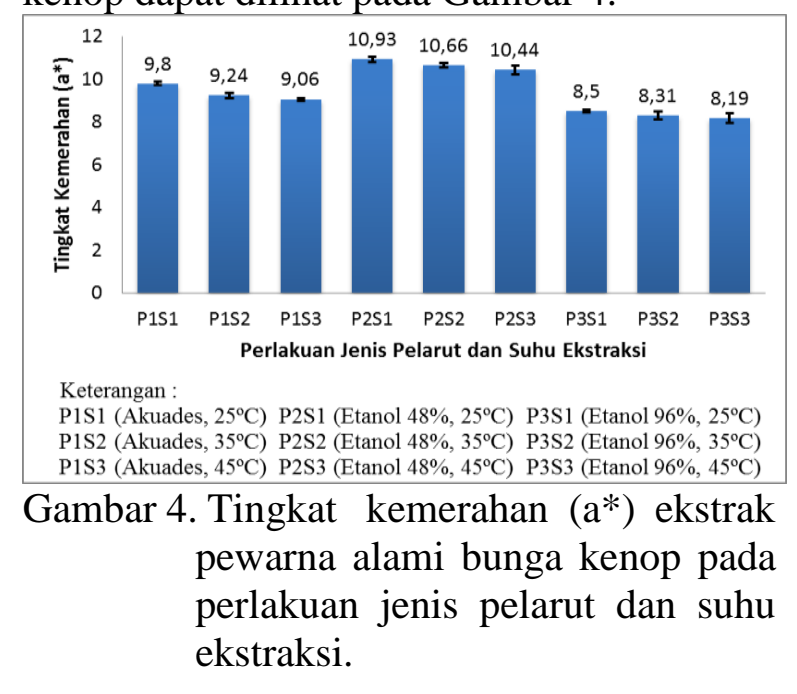

Gambar 4 menunjukkan tingkat kemerahan $\left(\mathrm{a}^{*}\right)$ ekstrak bunga kenop tertinggi pada perlakuan jenis pelarut etanol 48 persen dan suhu $25^{\circ} \mathrm{C}$ yaitu sebesar $10,93 \pm 0,13$ sedangkan tingkat kemerahan $\left(\mathrm{a}^{*}\right)$ terendah pada perlakuan jenis pelarut etanol 96 persen dan suhu $45^{\circ} \mathrm{C}$ yaitu sebesar $8,19 \pm 0,23$. Tingkat kemerahan $\left(a^{*}\right)$ tertinggi dihasilkan pada jenis pelarut etanol 48 persen dan mengalami penurunan pada jenis pelarut akuades dan etanol 96 persen. Hasil ini berhubungan dengan kadar total betasianin yang dihasilkan pada proses ekstraksi, semakin tinggi total betasianin maka nilai a* semakin meningkat. Penggunaan pelarut air:etanol (5:5) menghasilkan kadar betasianin yang tinggi sehingga intensitas warna merah bertambah dan mengakibatkan kenampakan ekstrak yang semakin gelap 
(Khuluq et al., 2007).

Perlakuan suhu ekstraksi menunjukkan menunjukkan bahwa nilai $a^{*}$ mengalami penurunan seiring peningkatan suhu ekstraksi yang digunakan pada semua jenis pelarut. Peningkatan suhu ekstraksi mengakibatkan terjadinya kerusakan pada pigmen betasianin yang mengakibatkan penurunan konsentrasi betasianin sehingga nilai a* pada ekstrak ikut berkurang. Azeredo (2009) dalam Yusmitha et al. (2017) menyatakan panas atau asam menyebabkan terdegradasinya betasianin yang dapat menyebabkan terjadinya isomerisasi, dekarboksilasi atau pembelahan yang berakibat terjadinya pengurangan warna merah ungu secara bertahap. Kenaikan dan penurunan intensitas warna merah dipengaruhi oleh kadar betasianin yang terkandung dalam bahan (Herbach et al. 2006).

\section{Tingkat Kekuningan (b*)}

Hasil analisis menunjukkan perlakuan jenis pelarut dan suhu ekstraksi menghasilkan tingkat kekuningan (b*) ekstrak pewarna alami bunga kenop berkisar antara 4,77 7,87. Nilai kekuningan (b*) menyatakan tingkat warna biru sampai kuning dengan kisaran -100 sampai +100 . Tingkat kekuningan $\left(b^{*}\right)$ ekstrak pewarna alami bunga kenop dapat dilihat pada Gambar 5.

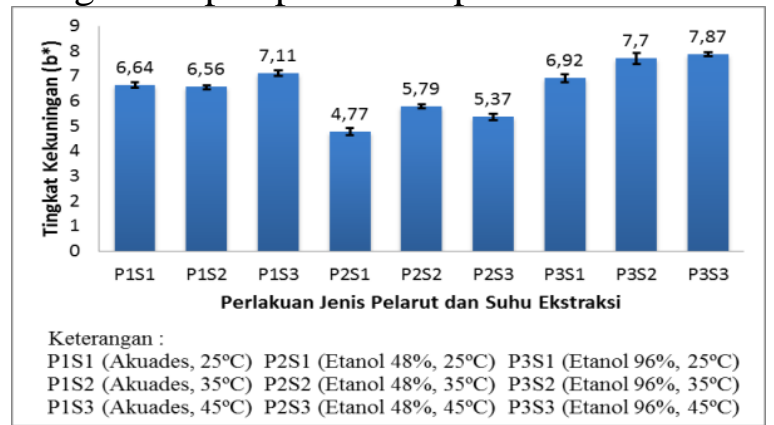

Gambar 5. Tingkat kekuningan $\left(b^{*}\right)$ ekstrak pewarna alami bunga kenop pada perlakuan jenis pelarut dan suhu ekstraksi.

Gambar 5 menunjukkan tingkat kekuningan $\left(b^{*}\right)$ ekstrak bunga kenop terendah diperoleh pada perlakuan jenis pelarut etanol 48 persen dan suhu $25^{\circ} \mathrm{C}$ yaitu sebesar 4,77 $\pm 0,14$ sedangkan tingkat kekuningan $\left(b^{*}\right)$ tertinggi pada perlakuan jenis pelarut etanol 96 persen dan suhu $45^{\circ} \mathrm{C}$ yaitu sebesar $7,87 \pm 0,08$. Tingkat kekuningan (b*) ekstrak bunga kenop mengalami penurunan berturut-turut pada perlakuan jenis pelarut etanol 96 persen, akuades, dan etanol 48 persen. Hasil ini menunjukkan bahwa kadar total betasianin yang tinggi akan berbanding lurus dengan penurunan nilai $b^{*}$ ekstrak bunga kenop. Peningkatan nilai $b^{*}$ menunjukkan penurunan konsentrasi betasianin yang memberikan pengaruh warna merah yang lebih besar dibandingkan warna kuning pada ekstrak (Khuluq et al., 2007).

Perlakuan suhu ekstraksi menunjukkan menunjukkan bahwa nilai $b^{*}$ mengalami kenaikan seiring peningkatan suhu ekstraksi yang digunakan pada semua jenis pelarut. Hal ini menandakan terjadinya degradasi pada betasianin sehingga terjadinya penurunan pigmen warna merah pada ekstrak. Zakharova dan Petrova. (2000) dalam Zyrd dan Christinet. (2003) menyatakan bahwa degradasi pigmen betasianin bersifat reversibel dan diikuti oleh sintesis pigmen kuning betaxantin dalam grup amina dengan peningkatan tingkat kekuningan $\left(b^{*}\right)$ disertai penurunan tingkat kemerahan $\left(\mathrm{a}^{*}\right)$.

\section{Korelasi Total Betasianin (X) dengan Rendemen (Y)}

Hasil analisis korelasi total betasianin dengan rendemen pada perlakuan jenis pelarut dan suhu ekstraksi ekstrak pewarna alami bunga kenop dapat dilihat pada Gambar 6.

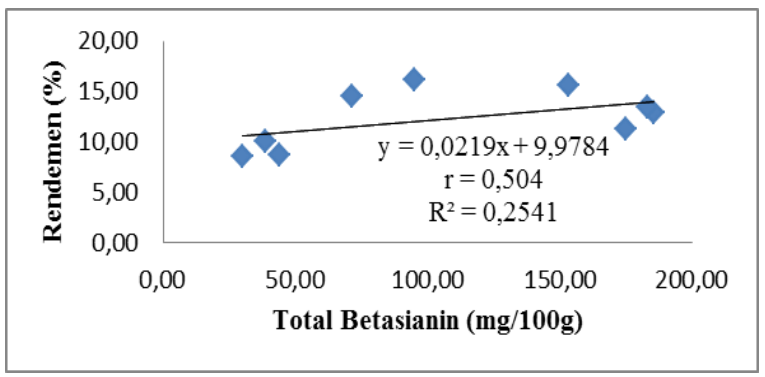


Gambar 6. Grafik korelasi total betasianin Dengan rendemen ekstrak pewarna alami bunga kenop pada perlakuan jenis pelarut dan suhu ekstraksi.

Gambar 6 menunjukkan korelasi total betasianin dan rendemen dengan persamaan regresi linier $y=0,0219 x+9,9784$ serta nilai koefisien korelasi sebesar 0,504. Hal ini menujukkan adanya hubungan positif atau searah antara variabel total betasianin dengan rendemen. Artinya kenaikan total betasianin akan diikuti oleh kenaikan rendemen ekstrak. Nilai koefisien korelasi sebesar 0,504 menunjukkan bahwa adanya hubungan yang kuat antara nilai total betasianin dan rendemen yang dihasilkan. Nilai koefisien korelasi $>0,5-0,75$ menunjukkan interpretasi hubungan yang kuat antara dua variabel (Sarwono dan Budiono, 2012). Sedangkan nilai probabilitas berdasarkan uji korelasi menunjukkan hasil yaitu sig 0,166>0,05 yang menandakan Ho diterima. Hal ini berarti korelasi antara total betasianin dengan rendemen tidak memiliki hubungan yang signifikan. Nilai koefisien determinasi (R2) yaitu sebesar 0,2541, hasil ini menunjukkan bahwa 25,41 persen keragaman yang muncul pada variabel rendemen dapat dijelaskan oleh variabel total betasianin. Sedangkan sisanya 74,59 persen dipengaruhi oleh variabel lainya.

\section{Korelasi Total Betasianin (X) dengan Intensitas Warna $\left(\mathbf{L}^{*}, \mathbf{a}^{*}, \mathrm{~b}^{*}\right)(\mathbf{Y})$}

Hasil analisis korelasi total betasianin dengan intensitas warna yaitu kecerahan, kemerahan, dan kekuningan pada perlakuan jenis pelarut dan suhu ekstraksi ekstrak pewarna alami bunga kenop dapat dilihat pada Gambar 7, 8, 9.

Gambar 7, 8, 9 menunjukkan korelasi total betasianin dengan tingkat kecerahan, tingkat kemerahan, dan tingkat kekuningan dengan persamaan regresi linier yaitu $\mathrm{y}=$ -
$0,0247 \mathrm{x}+17,263, \mathrm{y}=0,0157 \mathrm{x}+7,7606$, dan $\mathrm{y}=-0,0143 \mathrm{x}+8,0803$ dan nilai koefisien korelasi (r) berturut-turut yaitu -0,932, 0,986, dan $-0,907$.

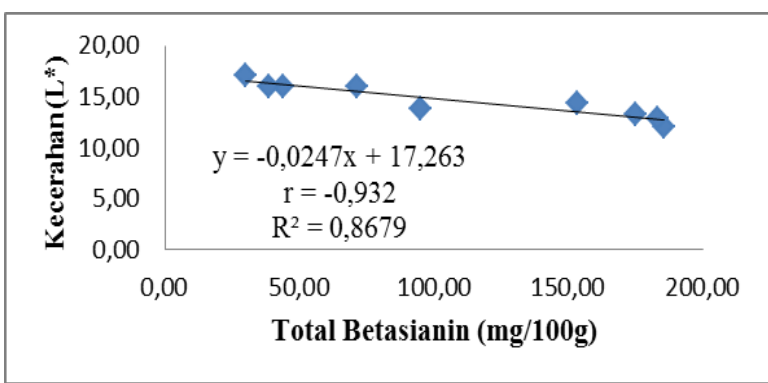

Gambar 7. Grafik korelasi total betasianin dengan kecerahan ekstrak pewarna alami bunga kenop pada perlakuan jenis pelarut dan suhu ekstraksi.

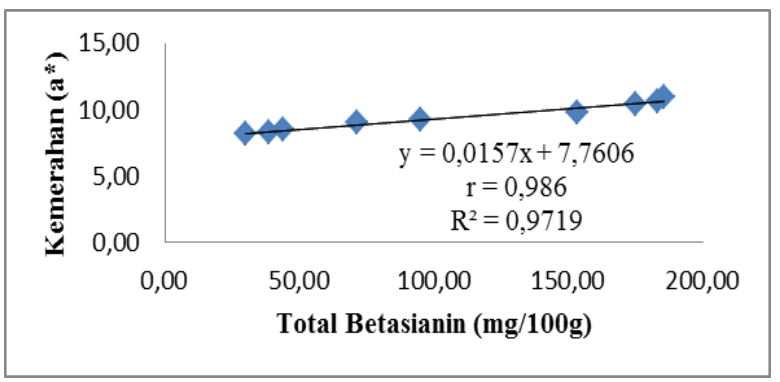

Gambar 8. Grafik korelasi total betasianin dengan kemerahan ekstrak pewarna alami bunga kenop pada perlakuan jenis pelarut dan suhu ekstraksi.

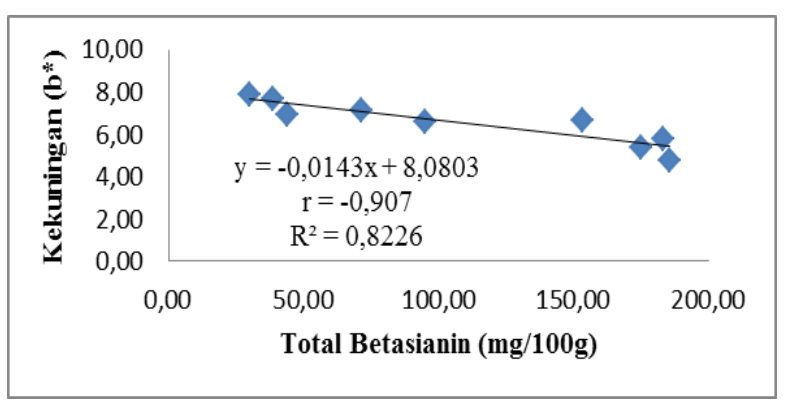

Gambar 9. Grafik korelasi total betasianin dengan kekuningan ekstrak pewarna alami bunga kenop pada perlakuan jenis pelarut dan suhu ekstraksi.

Hasil uji korelasi ini menunjukkan adanya hubungan yang positif antara total 
betasianin dengan tingkat kemerahan $\left(\mathrm{a}^{*}\right)$, artinya semakin tinggi total betasianin yang dihasilkan maka nilai a* juga semakin besar. Semakin tinggi konsentrasi betasianin dalam ekstrak memberikan kontribusi warna merah yang lebih tinggi (Khuluq et al., 2007). Sedangkan pada tingkat kecerahan ( $\left.\mathrm{L}^{*}\right)$ dan kekuningan $\left(b^{*}\right)$ menunjukkan hubungan yang negatif atau berlawanan arah. Hal ini berarti semakin tinggi total betasianin maka nilai $L^{*}$ dan nilai $b^{*}$ pada ekstrak akan semakin berkurang. Hasil ini sesuai dengan penelitian Kristamtini et al. (2018) bahwa variabel tingkat kecerahan $\left(\mathrm{L}^{*}\right)$ dan tingkat kekuningan $\left(b^{*}\right)$ berkorelasi negatif dengan antosianin total. Nilai koefisien korelasi (r) menunjukkan adanya hubungan yang sangat kuat antara total betasianin dengan tingkat kecerahan, kemerahan, dan kekuningan. Nilai koefisien korelasi >0,75 - 0,99 menunjukkan interpretasi hubungan yang sangat kuat (Sarwono dan Budiono, 2012). Berdasarkan uji korelasi antara total betasianin dengan tingkat kecerahan $\left(\mathrm{L}^{*}\right)$ dan tingkat kemerahan $\left(\mathrm{a}^{*}\right)$ menunjukkan nilai probabilitas 0,000 sedangkan dengan tingkat kekuningan $\left(b^{*}\right)$ menunjukkan nilai probabilitas 0,001 . Nilai probabilitas $<0,01$ menandakan Ho ditolak, yang artinya terdapat hubungan korelasi yang signifikan antara total betasianin dengan intensitas warna dengan tingkat kepercayaan 99 persen.

Nilai koefisien determinasi (R2) antara total betasianin dengan tingkat kecerahan (L*) yaitu sebesar 0,8679. Hasil ini menunjukkan 86,79 persen keragaman yang muncul pada variabel tingkat kecerahan $\left(\mathrm{L}^{*}\right)$ dapat dijelaskan oleh variabel total betasianin, sedangkan 13,21 persen dipengaruhi oleh variabel lainya. Sedangkan pada tingkat kemerahan $\left(\mathrm{a}^{*}\right)$ nilai koefisien determinasi (R2) yaitu sebesar 0,9719, artinya 97,19 persen keragaman yang muncul pada variabel tingkat kemerahan $\left(\mathrm{a}^{*}\right)$ dapat dijelaskan oleh variabel total betasianin, sedangkan 2,81 persen dipengaruhi oleh variabel lainya. Nilai koefisien determinasi (R2) pada tingkat kekuningan $\left(b^{*}\right)$ yaitu sebesar 0,8226, yang berarti 82,26 persen keragaman yang muncul pada variabel tingkat kekuningan $\left(b^{*}\right)$ dapat dijelaskan oleh variabel total betasianin, sedangkan 17,74 persen dipengaruhi oleh variabel lainya.

Nilai koefisien determinasi (R2) tertinggi pada penelitian ini terdapat pada nilai tingkat kemerahan $\left(a^{*}\right)$ yaitu sebesar 0,9719, hal tersebut menunjukkan bahwa total betasianin memiliki peranan yang paling dominan terhadap tingkat kemerahan (a*) yang dihasilkan. Hal ini didukung oleh penelitian Kristamtini et al. (2017) yang menyatakan bahwa nilai koefisien determinasi (R2) dapat menjelaskan keragaman yang muncul pada kandungan antosianin total oleh variabel warna $\left(\mathrm{L}^{*}, \mathrm{a}^{*}\right.$, $\left.b^{*}\right)$.

\section{KESIMPULAN DAN SARAN}

\section{Kesimpulan}

Berdasarkan penelitian yang telah dilakukan maka dapat disimpulkan beberapa hal sebagai berikut:

1. Karakteristik ekstrak pewarna alami bunga kenop pada perlakuan jenis pelarut dan suhu ekstraksi adalah sebagai berikut : rendemen 8,65 - 16,13 persen, total betasinain $30,01-185,51 \mathrm{mg} / 100 \mathrm{~g}$, tingkat kecerahan $\left(\mathrm{L}^{*}\right)$ 12,08 - 17,09, tingkat kemerahan $\left(a^{*}\right) 8,19-10,93$, dan tingkat kekuningan $\left(b^{*}\right) 4,77-7,87$.

2. Total betasianin berkorelasi positif dengan rendemen dan tingkat kemerahan (a*) dengan nilai koefisien korelasi (r) sebesar 0,504 (kuat) dan 0,986 (sangat kuat) serta nilai koefisien determinasi (R2) sebesar 0,2541 dan 0,9719, sedangkan total betasianin berkorelasi negatif dengan tingkat kecerahan $\left(\mathrm{L}^{*}\right)$ dan tingkat kekuningan $\left(b^{*}\right)$ dengan nilai koefisien korelasi (r) sebesar 0,932 (sangat kuat) dan 0,907 (sangat kuat) 
serta nilai koefisien determinasi (R2) sebesar 0,8679 dan 0,8226.

\section{Saran}

Berdasarkan hasil penelitian disarankan menggunakan jenis pelarut etanol 48 persen serta suhu ekstraksi $25^{\circ} \mathrm{C}$ untuk menghasilkan ekstrak pewarna alami bunga kenop. Perlu dilakukan pengulangan minimal sebanyak dua kali pada penelitian serta perlakuan lanjutan seperti enkapsulasi sehingga dapat diaplikasikan pada bahan pangan.

\section{DAFTAR PUSTAKA}

AOAC. 1999. Official Methods of Analysis (15th Ed.). K. Helrich (Ed.), Virginia.

Cai, Y., M. Sun, and H. Corke. 2001. Identification and distribution of simple and acylated betacyanins in the Amaranthaceae. Journal of Agricultural and Food Chemistry. 49: 1971-1978.

Chew, K. K., S.Y. Ng, Y.Y. Thoo, M.Z. Khoo, W.A.I. Mustapha, and C.W. Ho. 2011. Effect of ethanol concentration, extraction time and extraction temperature on the recovery of phenolic compounds and antioxidant capacity of Centella asiatica extracts. International Food Research Journal. 18: 571-578.

Coultate, T. P. 1996. Food the Chemistry of Its Components, $3 \mathrm{rd}$ edition. The Royal Society and Chemistry Company, Cambridge.

Dalimartha, S. 2000. Atlas Tumbuhan Obat Indonesia Jilid II. Trubus Agriwidya, Jakarta.

Damanik, D. D. P., N. Surbakti, dan R. Hasibuan. 2014. Ekstraksi katekin dari daun gambir (Uncaria gambir Roxb.) dengan metode maserasi. Jurnal Teknik Kimia USU. 3(2): 20-14.

Departemen Kesehatan Republik Indonesia. 1988. Peraturan Menteri Kesehatan RI No.722/Menkes/Per/IX/1988 Tentang

$\begin{array}{lr}\text { Bahan Tambahan } & \text { Makanan. } \\ \text { Kementerian Kesehatan } & \text { Republik } \\ \text { Indonesia, Jakarta. } & \end{array}$

Departemen Kesehatan Republik Indonesia. 2006. Monografi Ekstrak Tumbuhan Obat Indonesia. Depkes RI, Jakarta

Eder, R. 1996. Handbook of Food Analysis, Volume I. Marcel Dekker Inc, New York.

Khuluq, A. D., S. B. Widjanarko, dan E. S. Murtini. 2007. Ekstraksi dan stabilitas betasianin daun darah (Alternanthera dentata) (kajian perbandingan pelarut air:etanol dan suhu ekstraksi). Jurnal Teknologi Partanian. 8(3): 172-181.

Kirsten, M., Herbach, F. C. Stinzing, and R. Carle. 2006. Betalain stability and degradation structural and chromatic aspec. Journal of Food Science. 71(4): 41-50.

Kristamtini., Taryono, P. Basunanda, dan R.H. Murti. 2017. Korelasi kandungan antosianin total dengan peubah warna $\left(L^{*}, a^{*}, b^{*}\right)$ dan penanda mikrosatelit pada beras hitam. Penelitian Pertanian Tanaman Pangan. 1(2): 115-123.

Lestari, N., S. Priyono, dan D. Raharjo. 2017. Ekstraksi senyawa rasa awal pada daun sindu (Scorodocarpus borneensis) dengan pelarut etanol dan aquades. Jurnal Sains Mahasiswa Pertanian. 6(7): 1-9.

Margaretta, S., S.D. Handayani, N. Indraswati, dan H. Hindarso. 2011. Ekstraksi senyawa phenolic Pandanus amaryllifolius Roxb. sebagai antioksidan alami. Widya Teknik. 10(1): 21-30.

Naderi, N., H. M. Ghazali, A. S. M. Hussin, M. Amid, and M. Y. A. Manap. 2012. Characterization and quantification of dragon fruit (Hylocereus polyrhizus) betacyanin pigment extracted by two procedure. Pertanika Journal of Tropical Agricultural Science. 35: 3340. 
Pangesti, D. R. H. 2018. Identifikasi Pigmen dan Aktivitas Antioksidan Ekstrak Buah Naga. Skripsi (S1). Tidak Dipublikasi. Fakultas Teknologi Pertanian, Institut Pertanian Bogor, Bogor.

Rengku, P. M., A. Ridhay, dan Prismawiryanti. 2017. Ekstraksi dan uji stabilitas betasianin dalam ekstrak buah kaktus (Opuntia elatior Mill). Kovalen Jurnal Riset Kimia. 3(2): 142-149.

Roriz, C.B., L. Barros, M.A. Prieto, P. Morales, and I. C. F. R. Ferreira. 2017. Floral parts of Gomphrena globosa L.. As a novel alternative source of betacyanins: optimization of the extraction using response surface methodology. Food Chemistry. 229: 223-234.

Sarwono, J., dan H. Budiono. 2012. Statistik Terapan : Aplikasi untuk Riset Skripsi, Tesis, dan Disertasi Menggunakan SPSS, AMOS, dan Excel. Elex Media Komputindo, Jakarta.

Stinzing, F. C., and R. Carle. 2004. Functional properties of anthocyanins and betalains in plants, food, and in human nutrition. Trends in Food Science \& Technology. 15(1): 19-38.

Voight, R. 1994. Buku Pelajaran Teknologi Farmasi, diterjemahkan oleh Soedani, N. Universitas Gadjah Mada Press, Yogyakarta.
Weaver, C. 1996. The Food Chemistry Laboratory. CRC Press, Boca Raton, New York, London, Tokyo.

Winarno, F. G. dan R. T. Sulistyowati. 1994. Bahan Tambahan untuk Makanan dan Kontaminan. Gramedia, Jakarta.

Yudharini, G. A. K. F., A. A. P. A. S. Wiranata, dan N. M. Wartini. 2016. Pengaruh perbandingan bahan dengan pelarut dan lama ekstraksi terhadap rendemen dan karakteristik ekstrak pewarna dari buah pandan (Pandanus tectorius). Jurnal Rekayasa dan Manajemen Agroindustri. 4(3): 36-46.

Yulianti, H., R. Hastuti, dan D. S. Widodo. 2008. Ekstraksi dan uji kestabilan pigmen betasianin dalam kulit buah naga (Hylocereus polyrhizus) serta aplikasinya sebagai pewarna tekstil. Jurnal Kimia Sains dan Aplikasi. 11(3): 84-89.

Yusmita, L., A. Kasim, dan H. Nurdin. 2017. Pengaruh suhu ekstraksi dan konsentrasi asam sitrat terhadap pigmen betasianin daun kremah merah (Alternanthera dentata) dan aplikasinya pada pangan. Pro Food Jurnal Ilmu dan Teknologi Pangan. 3(1): 178-185.

Zyrd, P. J. and C. Laurant. 2003. Betalain Pigments.Universite de Lausanne, Switzerland. 